$\triangle$ CTA $\mathbb{N E O P H I L O L O G I C A}$

DOI: 10.4312/an.51.1-2.5-15
UDK: 821.111.09-311.9Ballard J. G.

UDK: 821.111(73).09-311.9VanderMeer J.

\title{
Vacuum Ecology: J.G. Ballard and Jeff VanderMeer
}

\section{Edita Jerončić, Brian Willems}

\section{Abstract:}

J.G. Ballard's novel The Drought (1965) reimagines an ecological dystopia into a strategy for how to live through the catastrophe of the Anthropocene. We suggest the term "vacuum ecology" for a literary strategy which represents a way to live in our current ecological crisis. Ballard describes how a near-total emptiness of time and space is one way to respond to a global ecological catastrophe. Using Ballard's novel as a guide, our concept of vacuum ecology is developed along with along with the work of Jason Moore, Roy Scranton and others. In The Drought, the concept of modulation is suggested as the mechanism for change. At the end of the essay, Jeff VanderMeer's Annibilation (2014), along with Catherine Malabou's notion of destructive plasticity, is seen as challenging the idea of modulation with a strategy of intermingling. In short, both texts foreground the possibility of new kinds of change when concepts of time and space are questioned. This has consequences for the different beings we must become in order to live in the Anthropocene.

Keywords: ecology, Anthropocene,J.G. Ballard,Jeff VanderMeer, modulation, plasticity 


\section{DYING IN THE ANTHROPOCENE}

Dystopian fiction often represents the future as a wasteland (Wolfe 125). However, J.G. Ballard's novel The Drought (1965) reconfigures the trope of the wasteland into a strategy for how to live through the horrors of human-induced climate change. Under the rubric of the vacuum, Ballard describes how a near-total emptiness of time and space is one way to respond to a global ecological catastrophe. Using Ballard's novel as a guide, our concept of vacuum ecology is developed along with a number of current ideas in eco-criticism. In The Drought, the concept of modulation is suggested as the mechanism for change. At the end of the essay, Jeff VanderMeer's Annibilation (2014) challenges the idea of modulation with a strategy of plasticity. In short, both texts foreground the possibility of new kinds of change when concepts of time and space are questioned. This change is necessary for life in our current age of ecological collapse.

Our current age of ecological ruin has been termed the Anthropocene by chemist Paul Crutzen (winner of the Nobel Prize in 1995 for work on the ozone layer). He suggests this term would replace the name for our current geological epoch, the Holocene (cf. Willems 30-2). Crutzen develops this term in order to name "the current epoch in which humans and our societies have become a global geophysical force" (Steffen, Crutzen and McNeill 614). Humans affect the earth on a global scale, and the consequences of human-action are becoming irreparable. Crutzen sees the Anthropocene starting in 1800 with the rise of industrialization in the Western world. More specifically, an increase of $\mathrm{CO} 2$ in the atmosphere is the main sign of humanity's influence on the planet. A rise of around $25 \mathrm{ppm}$ of atmospheric CO2 from 1800 to 1945 is taken as the start of the Anthropocene because this rise is a sign of human intervention (rather than natural $\mathrm{CO} 2$ release) which exceeds the margins of error for such studies (616).

However, starting the Anthropocene in 1800 is problematic because it suggests that the current state of the environment can be fixed if we just go back to pre1800 conditions. Instead, what needs to be addressed is the kind of thinking that has been behind an Anthropocenic relationship to the environment. Jason Moore makes a similar argument in Capitalism and the Web of Life, saying that starting the Anthropocene with the rise of the use of steam and coal "makes for an easy story. Easy, because it does not challenge the naturalized inequalities, alienation, and violence inscribed in modernity's strategic relations of power and production. It is an easy story to tell because it does not ask us to think about these relations at all' (Moore 170). In other words, limiting the problem to the effects of industrialization limits solutions to alternative to the same effects, rather than finding solutions in different ways of thinking about the world: "to locate the origins of the modern world with the steam engine and the coal pit is to prioritize shutting 
down the steam engines and the coal pits (and their twenty-first century alternatives)" (172). Moore alternatively starts the Anthropocene in 1450, with the rise of capitalism rather than industrialization (182-27). This new date foregrounds strategies of "global conquest, endless commodification, and relentless rationalization" which, instead of focusing on coal and steam, can "prioritize the relations of power, capital, and nature that rendered fossil capitalism so deadly in the first place." In other words, "Shut down a coal plant, and you can slow global warming for a day; shut down the relations that made the coal plant, and you can stop it for good" (172).

This is where Ballard's work comes in: it posits a new set of relations to the world, and to the self, in the midst of ecological collapse. This is similar to the work of Roy Scranton, who argues that there is actually a need to learn how to die in the Anthropocene, meaning that we are going to need "a new conceptual understanding of reality, and a new relationship to the deep polyglot traditions of human culture that carbon-based capitalism has vitiated through commodification and assimilation" (Scranton 19). In other words, our old relations to time and space need to "die" in order for new relations to form. There are different ways to respond to this call for a new relationship to the world in the Anthropocene. In The Mushroom at the End of World (2015), Anna Tsing argues for the need of interconnectedness in the ruins of the environment (cf. also Maver), and in The Great Derangement (2017), Amitav Ghosh specifies the "as if" available to literature for imagining new possibilities (Ghosh 128-9). However, Ballard takes a different track. In The Drought, Ballard argues that the kind of "death" of the old self that Scranton calls for is actually a new way of life. Leaving behind the past ways of relating to the planet makes room for new relations to arise. One way for this "death" of the old self to take place is through a representation of the vacuum, meaning a removal from the destructive notions of time and space that led to the Anthropocene.

\section{BALLARD'S VACUUM}

Ballard's The Drought is the British title of what was called The Burning World (1964) when published in America. It is a science fiction novel set in the Anthropocene. It is one of his first four novels, all dealing with ecological catastrophes. The global disaster described in The Drought is reflected not only in the environment, but in the characters' personal lives as well. Empty landscapes are mirrored by the lack of connection between people and where they live. This reflects how Ballard is not particularly interested in the outer space of science fiction, but mainly the fluctuations in "inner space" (Ballard 1996: 197) demanded by radical changes to the environment. 
Throughout The Drought we see how different characters deal with the unknown situation of learning to live in a dried-out landscape. As Rob Latham argues, Ballard "appears fundamentally uninterested either in explaining the disasters ... or in depicting valiant efforts to fend off their ravages. Instead, the protagonists struggle towards a private accommodation with the cataclysms, a psychic attunement to their radical reorderings of the environment" (Latham 106). In The Drought, some characters refuse to cope with the problem, ignoring it and dwelling in their memories. Just as bad, some of the characters dream of a better future "with a wild misanthropic hope" (Ballard 1968: 47). All such characters are lost in their illusions and they eventually punished with death. Other characters, however, come to terms with the new world of the drought. These characters survive because they accept where they are instead of getting lost in nostalgia for the past or hope for the future. The way they survive is by having no hope for change. This removal from hope takes place through a vacuum of space and time. Yet, instead of being just a bleak acceptance of the present, it will be argued below that this is an ecological stance toward the future.

The novel tells the story of a global drought with no end in sight. People panic, head to the oceans, but only find more chaos. At the beginning of the novel, Dr Charles Ransom lives on a river in a houseboat. As the river dries up, Ransom's boat and the domestic life it contains lose their meaning. This loss is described in terms of a vacuum:

The house reflected this domestic and personal vacuum. The neutral furniture and decorations were as anonymous and free of associations as those of a motel - indeed, Ransom realized, they had been unconsciously selected for just this reason. In a sense the house was a perfect model of a spatio-temporal vacuum, inserted into the continuum of his life by the private alternate universe in the houseboat on the river. Walking about the house he felt more like a forgotten visitor than its owner, a shadowy and ever more evasive double of himself. (28-29)

Ransom's home is a mirror of the drought outside. The river used to link one part of the country to another, until it dried up, isolating the different parts it previously connected: "With the death of the river, so would vanish any contact between those stranded on the drained floor" (11). In a similar way, Ransom's home now feels like a motel because there are no connections between the furniture, decorations and the history of the occupants. This lack of connection is why the trope of the vacuum is used, indicating the difference between life before the drought, which is one of life, home and continuity, and life after the drought, which is one of shadows, evasiveness and lack of association. Although, as D. Harlan Wilson has argued, Ransom "always" thought of his life as a disaster, both 
before the drought and after (Wilson 51), Ransom is sure that this change is important, for everyone "would soon literally be an island in an archipelago drained of time" (Ballard 1968: 12).

This is not the only time that the trope of a vacuum makes a direct appearance in the novel. However, all the other direct references to a vacuum function in a similar manner: "his continued presence in the deserted town, his apparent acceptance of the silence and emptiness, in some way exposed the vacuum in their lives"(34); "Just as his own stratified personality reflected his preoccupation with the vacuums and drained years of his memory, so Lomax's had been formed by his intense focus upon the immediate present, his crystallization on the razor's edge of the momentary impulse" (40); and "During their journey to the south he had felt an increasing sense of vacuum, as if he was pointlessly following a vestigial instinct that no longer had any real meaning for him. The four people with him were becoming more and more shadowy, residues of themselves as notional as the empty river" (87). The idea of vacuum in all three examples has a similar function, which is to show Ransom's loss of connection to the meaning of the past and to people around him. On the one hand the vacuum represents how Ransom has surrendered to his destiny. He has become so numb that he does not find any sense in trying to understand the environmental changes around him, nor does he attempt to fight them. This external vacuum of the drought also functions as a mirror of Ransom's inner vacuum: the silence and emptiness of his life resemble the silence and emptiness of his house and of the whole environment. Thus the trope of the vacuum in The Drought represents an absence of time and space in the outer world as well as in Ransom's inner space. Yet at the same time, the vacuum contains something positive. It actually provides an opportunity for change, for the new kind of thinking and acting that Scranton calls for in the quote above. The reason for the possibility for change has to do with the physical properties of vacuums themselves.

In Humankind, Timothy Morton describes how a vacuum can be used as a figure for change. Vacuums cannot be made perfectly, there is always some remnant of matter. However, a small object close to absolute zero in a vacuum starts to display some strange qualities, including a "profound ambiguity" (Morton 82) which is due to the superposition principle, which is "If a quantum can be in either of two states, then it can be in both states at the same time" (Hobson 187). Or, as Morton puts it, superposition is "where a weird overlap between two physical systems...can occur" (Morton 82). This overlap is not a mixture of two things, but rather two different things occurring at the same time (Hobson 187-8). This is why Morton uses the superposition principle as a figure for change: it indicates that an object is not just one thing, it can also be something else. What is essential for this discussion is that one way to observe this change is in a vacuum, for then an object shows its "shifty qualities: the way in which it is smeared into itself, 
or vibrating and not-vibrating at the same time, or shimmering without being pushed in a mechanical way" (Morton 82).

In The Drought, Ransom is in a vacuum, which is represented by a lack of associations to both the past and those around him. And being in this vacuum demands change, it demands a profoundly ambiguous relationship to the concepts of time and space to which he had previously been accustomed (Willems 191-2). This new state of mind can be seen in how Ransom's way of thinking is contrasted to that of the zoo-keeper Catherine, who still has a hope for a better future. Ransom "crossed the bridge and turned left into a side-road. Sooner or later he would have to leave Catherine. Her barely conscious determination to stay on reminded him of his own first hopes of isolating himself among the wastes of the new desert, putting an end to time and its erosions. But now a very different kind of time was being imposed upon him" (Ballard 1968: 76-7). In a sense, in the words of Malcolm Miles, the novel is "a narrative of human endurance against a radically other, uncaring Nature" (Miles 81), but this is true only with an overly optimistic reading. The novel is really about "endurance" in that the tragic, unchanging time of the drought must not be ignored. This new kind of time of the drought is developed when Ransom reaches the beach, which initially offered the hope of a source of water during the drought but it is overcrowded and access to it is rigidly controlled. The beach is just a "zone of nothingness" (Ballard 1968: 133). On the beach "time was not absent but immobilized" (ibid.). The relationships of the past are over. But how does this "death" in the Anthropocene relate to change? This is the topic of the next section.

\section{CHANGE AS MODULATION}

In order to develop the relationship between change and the immobilized time and space of the vacuum, we can look at Steven Shaviro's concept of modulation. Shaviro bases his reading on a Deleuzian topology, so a brief background needs to be provided.

Much of the thought of Gilles Deleuze can be understood in relation to extensive and intensive properties (DeLanda 19-25). Extensive properties such as height, weight and length can be cut and divided, while intensive properties such as pressure and temperature "cannot be divided without involving a change in kind" (25). Deleuze is an intensive philosopher, meaning that he is interested in forces and properties which involve change, but not a change in kind. He is not interested in the change of a human into an animal, but rather in the change of a human into a human-animal, retaining the properties of one kind while expanding it towards another (Deleuze and Guattari 242). A vacuum can be considered an example of an intensive concept. A vacuum cannot be cut in half, as with extensive properties. 
Either there is an absence of air pressure, or there is not. However, what is more important for this essay is that the concept of the vacuum has intensive effects in the novel, how it can encourage Ransom to become something other than he was, without becoming something else entirely. This is one way to die and live in the Anthropocene. In order to develop this thought, Shaviro's work is key.

In the second chapter of Post-Cinematic Affect Shaviro uses the video for Grace Jones' song "Corporate Cannibal” to develop two concepts: modulation and metamorphosis. In short, modulation is an intensive force, while metamorphosis is extensive. An important aspect of Shaviro's argument is that modulation takes place in a vacuum-like space, which can be seen in an early description he gives of Jones' video: "there is literally nothing in the video aside from Jones' skin, her features and her silhouette. Behind her, there is only an empty blankness; it is this absence of any image whatsoever that we see as white" (Shaviro 11). The "nothingness," "empty blankness" and "absence" that he mentions mirror some of the characteristics of the vacuum. Shaviro calls this relational space and he argues that it represents "processes which do not occur in space but define their own spatial frame" (16).

This description illustrates how the vacuum works in The Drought. Rather than occurring in the pre-drought understanding of space the characters have spent their lives developing, a new spatial frame has been defined with the never-ending drought (although there does seem to be some relief at the end of the novel). At the same time, The Drought punishes characters who try to escape where they are, imagining totally new scenarios for the future (that it will rain someday). These future-planning characters are examples of metamorphosis, an extensive property, because they want to cut themselves off from the present in order to invent a new world that does exist. As Shaviro says, "Metamorphosis gives us the sense that anything can happen, because form is indefinitely malleable" (13). This is a negative description. "Anything can happen" is a sign of extension: one form is cut from what it is now, and can be anything else. Modulation, on the other hand, "requires an underlying fixity" (13). Ransom is not escaping from where he is, but is fixed to the present in a way that others are not. The removal of time and space in the vacuum causes Ransom to be completely in the present, with no hope of escape. Paradoxically, by being stuck in the catastrophe of the present, Ransom is able to question the forms of time and space that led to ecological collapse. For, as D. Harlan Wilson says of Ballard's early eco-novels, "they are all about timelessness insofar as they put the nature and structure of time into question, exposing the socially and culturally constructed ways in which we perceive and experience time" (Wilson 59). A comparison with a more contemporary piece of eco-fiction will help bring the structure of the questioning to light, and expand it in one important way. 


\section{PLASTIC METAMORPHOSIS}

In Jeff VanderMeer's novel Annibilation (2014), the first book of his Southern Reach Trilogy (2014), the absence of space and time is replaced by their intertwining. Both are still put into question, but rather than insisting on the strict separation between modulation and metamorphosis, the novel posits a relation between the two. The state of Area X, an ecological anomaly in which much of the novel takes place, could be described as the opposite of a vacuum because nature is everywhere, sometimes even inside the characters themselves. One consequence of this fullness is that we see the interconnection between human and non-human which is so close that it is almost impossible to decide where humans end and nature begins. This is an illustration of the Anthropocene, in which human activity is nature, having a global effect, and has thus become another physical force.

The plot of the novel follows a group of four women, a biologist, a psychologist, an anthropologist and a surveyor, who volunteer to be the twelfth group to investigate Area X, a secluded area in which some strange things have happened. The members of previous expeditions changed drastically, losing the traits of the people they used to be. They became animals, or other creatures and objects, and they are still in some way present in Area X. They have retained some of their recognizable human features, such as a human eye or human brain cells. However, they have become different categories of living beings. One important event is that in Area X they find a tunnel, home of a strange and unidentified creature that the biologist names the Crawler.

The following quote from when the biologist encountered the Crawler paints an image of an endless creature that is never fully comprehensible to humans. The interesting thing about the quote is that an extensive quality is used, size: "Then it became an overwhelming hugeness in my battered vision, seeming to rise and keep rising as it leapt toward me. The shape spread until it was even where it was not, or should not have been" (VanderMeer 176-8). This description of the Crawler describes a lack of comprehension of the Crawler's form. This mirrors how the Crawler leaves the characters in the novel confused. However, this confusion is described using an extensive quality, that of size ("bugeness") rather than through intensive properties such as pressure (or lack of, as found in a vacuum). The use of an extensive property indicates that Annibilation is working in a different way than The Drought. Yet this extensive property has the same effect as intensive properties in Ballard's novel. The last sentence from the quote depicts a questioning of time and space. But it does not describe an absence of time and space, rather their intermingling. This has the effect of making characters and events in Area X unpredictable. The strangeness of things which exist in this area leave the biologist perplexed: "As they [the dolphins] slid by, the nearest one rolled slightly to the 
side, and it stared at me with an eye that did not, in that brief flash, resemble a dolphin eye to me. It was painfully human, almost familiar" (97). Everything that exists in Area $\mathrm{X}$ exists in confusing and inexplicable forms. It is this confusion that allows one form to begin to infiltrate another.

Yet the figure of the Crawler is not just "extensive," it also has features of modulation, as seen in the following description of it: "Did I say I had seen golden light? As soon as I turned that corner entire, it was no longer golden but bluegreen [...]. As I adjusted to the light, the Crawler kept changing at a lightning pace, as if to mock my ability to comprehend it" (176). The Crawler changes so fast that it becomes incomprehensible to human senses. One second it is golden light, another second it is blue-green and then it turns into the sea, changing form, shape and structure completely. It changes drastically, but, as with modulation, it always remains the Crawler, representing all of its possible variations at the same time. This type of change brings to mind the image of Grace Jones in "Corporate Cannibal," which also changes form, but remains the same entity. The Crawler is at the same time a figure of profound change. The man who become the Crawler can never go back to just being a man. This is a sign of metamorphosis. In fact, it seems that the Crawler contains features of both modulation and metamorphosis, of both intensive and extensive properties.

Philosopher Catherine Malabou has developed one of the strongest arguments for combining modulation and metamorphosis. In Ontology of the Accident, she describes her concept of destructive plasticity, in which one person, a person suffering from Alzheimer's disease, for example, exhibits both the properties of fixity (they are the same person) and profound change (they also become someone else): "There are some transformations that are attacks on the individual...We must all of us recognize that we might, one day, become someone else, an absolute other, someone who will never be reconciled with themselves again, someone who will be this form of us without redemption or atonement, without last wishes, this damned form, outside of time" (Malabou 2-3). Malabou argues that change, once again, takes place outside of the time of the present. Yet she also argues that the separation between modulation and metamorphosis (which we have exaggerated in Shaviro's work) is too simple. Even in metamorphosis, meaning the complete and irreversible transformation of one being into another, contains elements of modulation. To illustrate this point, Malabou turns back to the mythological story of Daphne in Ovid's Metamorphosis. Daphne's transformation from a woman to a laurel tree does not negate the person she was before: "the being-tree nonetheless conserves, preserves, and saves the being-woman" (12). The Crawler is also such a figure: what is frightening about it is that it is both the complete transformation of a man into something else, and the preservation of that man within the creature. In this way, "destruction too is formative" (4), meaning the complete 
separation of one form from another found in metamorphosis is not just about the end of one form, but the creation of a new figure which also contains the old.

The kind of transformation that people in Area X undergo is indeed an attack on the old individual, who hopes for the future. In its place is a figure of intermingling, of modulation within metamorphosis. However, first a vacuum is needed. The vacuum means the death of previous relations to time and space, those which lead us into the Anthropocene. Thus these novels contain important images for the Anthropocene. If we abandon the world as it is, and focus on new worlds of technological invention, all is lost. The Drought shows the first step in this formation: living in the time of collapse. Annibilation shows the second: the formation of a new being that does not abandon the old, but which cannot go back to the old forms either. Thus Malabou's reading of destructive plasticity contains an antidote for dystopia. The destruction of ecological collapse is also formative because challenging the old notions of time and space has two effects: it signals the end of the way of life that led us into the Anthropocene, and it suggests a new way of living with our old selves in a new world.

\section{BIBLIOGRAPHY}

Ballard, J.G. The Drought. Harmondsworth, UK: Penguin Books Ltd, 1968. Ballard,J.G. A User's Guide to the Millennium. London: Picador, 1996.

DeLanda, Manuel. Intensive Science and Virtual Philosophy. London: Continuum, 2004.

Deluze, Gilles. and Félix Guattari. A Thousand Plateaus: Capitalism and Schizophrenia.

Trans. Brian Massumi. Minneapolis: University of Minnesota Press, 1987.

Ghosh, Amitav. The Great Derangement: Climate Change and the Unthinkable.

Chicago: University of Chicago Press, 2016.

Hobson, Art. Tales of the Quantum: Understanding Physics' Most Fundamental Theory.

Oxford: Oxford University Press, 2017.

Latham, Rob. "Biotic Invasions: Ecological Imperialism in New Wave Science

Fiction.” The Yearbook of English Studies 37.2 (2007): 103-119.

Malabou, Catherine. Ontology of the Accident: An Essay on Destructive Plasticity. Cambridge, UK: Polity Press, 2012.

Maver, Igor. “An Australian Poet in Italy. A.D. Hope's Byronic View of Latter-day Italy". Acta Neophilologica, 2017, 50/1-2: 57-68.

Miles, Malcolm. Eco-Aesthetics: Art, Literature and Architecture in a Period of Climate Change. London: Bloomsbury, 2014. 
Moore, Jason. Capitalism in the Web of Life: Ecology and the Accumulation of Capital. London: Verso, 2015.

Morton, Timothy. Humankind: Solidarity with Nonbuman People. London: Verso, 2017.

Scranton, Roy. Learning to Die in the Anthropocene: Reflections on the End of a Civilization. San Francisco: City Lights Books, 2015.

Shaviro, Shaviro. Post-Cinematic Affect. Winchester, UK: O-Books, 2010.

Steffen, Will, Paul Crutzen and John McNeill. "The Anthropocene: Are Humans Now

Overwhelming the Great Forces of Nature?" Ambio 36.8 (2007): 614-621.

Tsing, Anna. The Mushroom at the End of the World: On the Possibility of Life in Capitalist Ruins. Princeton: Princeton University Press, 2015.

VanderMeer,Jeff. Annibilation. New York City, NY: Farrar, Straus and Giroux, 2014. Willems, Brian. Speculative Realism and Science Fiction. Edinburgh: Edinburgh University Press, 2017.

Wilson, D. Harlan. J.G. Ballard. Urbana: University of Illinois Press, 2017.

Wolfe, Gary. The Known and the Unknown: The Iconography of Science Fiction. Kent: Kent State University Press, 1979.

Edita Jerončić University of Split edijer@ffst.hr

Brian Willems University of Split bwillems@ffst.hr

\section{Vakuumska ekologija: J. G. Ballard in Jeff VanderMeer}

Roman J. G. Ballarda The Drought (1965) pretvarja ekološko distopijo v strategijo, kako preživeti katastrofo antropocena. Avtorja predlagata izraz „vakuumsko ekologijo“ za literarno strategijo, ki predstavlja način življenja v trenutni ekološki krizi.

Ključne besede: ekologija, antropocen, J. G. Ballard, Jeff VanderMeer, modulacija, plastičnost 